\title{
İlkokul Öğretmenlerinin Örgütsel Bağlılıkları ile Mesleki Tükenmişlik Algıları Arasındaki İlişki ${ }^{*}$
}

\section{The Relationship between Organizational Commitment and Professional Burnout Perception of Elementary Teachers}

\begin{abstract}
Cevat ELMA**
Yusuf ERGEN ${ }^{* * *}$ id

Received: 19 April 2018

Research Article

Accepted: 20 May 2019

ABSTRACT: Both the commitment and professional burnout of primary school teachers can have a direct impact on the general and specific objectives of the school and therefore on the students. Therefore, it was important to examine the organizational commitment and professional burnout perceptions of primary school teachers and the relationship between these two variables if any in order to make the students start a quality education and training life. The aim of study is determine relationship between organizational commitment and professional burnout perception of elementary teachers. Research's data is collected with Organizational Commitment Scale and Maslach Burnout Scale. Sample of research consisted of 272 elementary school teachers whom working in Bayburt. According to research results there was positive, mid-level and significant relationship between complience sub-dimention of organizational commitment and professional bornout; negative, low-level and significient relationship between Identification subdimention and professional bornout; negative, mid-level and significient relationship between Internalization subdimention and professional bornout. Basides, elementary school teachers's perception of professional bornout is a significant predictor of dimentions of organization commitment and explain separately $7 \%$ of total variance in complience and Identification sub-dimention, $14 \%$ of total variance in internalizetion sub-dimention.
\end{abstract}

Keywords: elementary teacher, organizational commitment, professional burnout.

ÖZ: İlkokul öğretmenlerinin hem okul örgütüne olan bağlılıkları hem de mesleki tükenmişlikleri okulun genel ve özel amaçlarına dolayısıyla da öğrencilere doğrudan etki edebilir. Bu nedenle öğrencilerin kaliteli bir eğitim-öğretim hayatı başlangıcı yapabilmeleri için ilkokul öğretmenlerinin örgütsel bağlılıklarının ve mesleki tükenmişlik algılarının incelenmesi; bu iki değişkenin varsa birbirleri ile ilişkisinin belirlenmesi önemli görülmüştür. Bu çalışmanın amacı, ilkokul öğretmenlerinin örgütsel bağll1ıkları ile mesleki tükenmişlik algıları arasındaki ilişkinin belirlenmesidir. Araştırma verilerinin toplanması için Örgütsel Bağl1lık Ölçeği ve Maslach Tükenmişlik Ölçeği kullanılmıştır. Araştırmanın örneklemini Baybut’ta çalışan 272 ilkokul öğretmeni oluşturmaktadır. Araştırmada, örgütsel bağl1lığın uyum alt boyutu ile mesleki tükenmişlik arasında pozitif yönlü, orta düzeyde ve anlamlı bir ilişki; özdeşleşme alt boyutu ile mesleki tükenmişlik arasında negatif yönlü, düşük düzeyde, anlamlı bir ilişki; içselleştirme alt boyutu ile mesleki tükenmişlik arasında negatif yönlü, orta düzeyde, anlamlı bir ilişki bulunmuştur. İlkokul öğretmenlerinin mesleki tükenmişlik algısının örgütsel bağlılık alt boyutlarının anlamlı bir yordayıcısı olduğu; uyum ve özdeşleşme alt boyutlarındaki toplam varyansın ayrı ayrı \%7'sini, içselleştirme alt boyutundaki toplam varyansın ise \%14'ünü açıkladığı sonucuna ulaşılmıştır.

Anahtar kelimeler: ilkokul öğretmeni, örgütsel bağl1lık, mesleki tükenmişlik.

\footnotetext{
${ }^{*}$ Bu çalışma 15. Uluslararası Sınıf Eğitimi Sempozyumunda özet bildiri olarak sunulmuştur.

*** Corresponding Author: Assoc. Prof. Dr., Ondokuz Mayıs University, Samsun, Turkey, cevat.elma@omu.edu.tr, https://orcid.org/0000-0001-8943-8727

***** Asst. Prof. Dr., Bayburt University, Bayburt, Turkey, yergen@ bayburt.edu.tr, http://orcid.org/0000-0003-43135354

Citation Information

Elma' C., \& Ergen, Y. (2019). İlkokul öğretmenlerinin örgütsel bağlılıkları ile mesleki tükenmiş̧lik algıları arasındaki İlişki. Kuramsal Eğitimbilim Dergisi [Journal of Theoretical Educational Science], 12(3), 874-891.
} 


\section{Giriş}

İlkokul öğretmenleri, öğrencilerin hem sosyal hem de akademik yaşamlarının şekillenmesinde önemli role sahiptir. Bu öğretmenlerin yüksek iş performansları ve ortaya koydukları olumlu model, öğrencilerin akademik ve sosyal becerilerinin gelişimine yardımcı olabilir. Çünkü çalıştığı okul örgütüne bağlılığı yüksek, mesleğinin gereklerini yerine getirmek için sürekli çalışan, öğrenen ve kendini yenileyen bir ilkokul öğretmeni ile temellendirilen eğitim-öğretim hayatı bütün öğrenciler için iyi bir başlangıç sayılır.

İlkokul öğretmenlerinin örgütsel bağlllıklarının ve mesleki tükenmişliklerinin onların iş performansını ve verimliliğini etkileyebilecek değişkenler olduğu düşünülmektedir. İlkokul öğretmenlerinin hem okul örgütüne olan bağlılıkları hem de mesleki tükenmişlikleri okulun genel ve özel amaçlarına dolayısıyla da öğrencilere doğrudan etki edebilir. Bu nedenle öğrencilerin kaliteli bir eğitim-öğretim hayatı başlangıcı yapabilmeleri için ilkokul öğretmenlerinin örgütsel bağlılıklarının ve mesleki tükenmişlik algılarının incelenmesi; bu iki değişkenin varsa birbirleri ile ilişkisinin belirlenmesi önemli görülmüştür.

\section{Örgütsel Bağlılık}

Örgütsel bağlılık, çalışanın örgütün amaçlarını benimsemesini ve özelliklerini kabullenmesini sağlayan, çalışanın örgüte uyum sağlamasıyla ilgili örgüte yönelik hissettiği psikolojik ilgidir (O’Reilly \& Chatman, 1986, s. 492). Meyer ve Allen'e (1997) göre örgütsel bağlılık, işgörenin işine devam etmeye istekli olması, işyerine düzenli olarak gelmesi, örgütün varlıklarını koruması ve örgütün amaçları ile bütünleşmesidir. Örgütsel bağlılık, çalışanın örgütün amaçlarını ve değerlerini özümsemesini ve bunları içselleştirmesini gerektirir (Balay, 2012, s. 2475). Örgütsel bağlılık; müdüre, iş arkadaşlarına, üst yönetime ve örgüte bağlı olmayı ifade eder (Becker, Meyer \& Vandenberghe, 2004, s. 994).

Öğretmenlerin işle ilgili davranışlarını anlamada örgütsel bağlılık, önemli bir faktördür (Mosheti, 2013, s. 55). Tsui ve Cheng (1999) öğretmenlerin örgütsel bağlılığını, kendilerini çalıştıkları okul ile güçlü şekilde özdeşleştirmeleri ve okulun işleyişine haz duyarak dâhil olmaları biçiminde ifade etmektedir. Steers'a (1977) göre çalışanların örgütsel bağlılıkları yüksek olduğunda örgütle ilgili işler için daha fazla çaba harcamaktadırlar. Bu durumu destekler nitelikte Chow (1994) çalışanların yüksek bağlılıklarının sadakatlerinde, verimliliklerinde ve sorumluluk sahibi olmalarında artışla sonuçlandığını ifade etmektedir. Buna göre örgütsel bağlılı̆̆ı yüksek öğretmenlerin okulun amaçları ile ilgili çalışmalarda daha etkili ve verimli sonuçlar elde etmeleri beklenebilir. Öğretmenler için örgütsel bağlılık, okulla ilgili bütün değişkenler tarafından etkilenebilir. Okul idaresinde, öğretmen kadrosunda, veli profilindeki değişiklikler; eğitim politikalarındaki değişiklikler; öğretmenin özel yaşamındaki değişiklikler öğretmenlerin örgütsel bağlılıklarını etkileyebilir. Dinamik bir yapıya sahip olan eğitim sisteminde bu değişikliklerin yaşanması beklenen bir durumdur. Bu nedenle öğretmenlerin örgütsel bağlılıklarının farklı boyutlarla ve belirli aralıklarla ölçülmesi gerekir. İlgili çalışmalar incelendiğinde, örgütsel bağlılığın alanda çalışan yazarlar tarafından farklı isimlerle boyutlandırıldığı görülmektedir. Katz ve Kahn (1977) örgütsel bağlılı̆̆ , anlatımsal ve araçsal bağl1lık; Mowday, Porter ve Steers (1982) tutumsal bağlılık ve davranışsal bağlılık; O’Reailley ve Chatman (1986) uyum, özdeşleşme ve içselleştirme; Meyer ve Allen (1991) ise duygusal bağlılık, devam 
bağl1lı̆ğ ve normatif bağlılık olarak sınıflandırmışlardır. Son zamanlarda yapılan çalışmalarda Meyer ve Allen'in (1991) sınıflandırması daha çok kullanılmaktadır. Bu çalışmada ise Balay'ın (2000), O'Reailley ve Chatman (1986) tarafindan yapılan boyutlandırmayı temel alarak yaptığı (Uyum, Özdeşleştirme ve İçselleştirme) örgütsel bağlılık sınıflandırması esas alınmıştır. Bu sınıflandırmaya göre uyum; tutum ve davranışların özel ödüller kazanıldığında benimsenmesiyle oluşur. Özdeşleşme, kişisel olarak bir ilişkinin kurulup devam ettirilmek istenmesi durumunda oluşur. Özdeşleşme boyutunda kişi grubun parçası olmaktan gurur duyar, grubun başarılarına ve değerlerine onları kendisinin olarak görmeden saygı duyar. İçselleştirme, kişinin kendi değerleri ile grubun tutum ve davranışlarının uyuşması durumunda ortaya çıkar. Yani kişinin, grubun ya da örgütün değerlerinin aynı olması durumudur (O'Reailley \& Chatman, 1986, s. 493).

\section{Mesleki Tükenmişlik}

Tükenmişlik, daha fazla enerji, güç ve kaynak taleplerinden dolayı kişinin başarısız olması, yorulması ve yıpranmasıdır (Freudenberger, 1974, s. 159). Maslach ve Jacson (1981) ise tükenmişliği duygusal tükenme, duyarsızlaşma ve kişisel başarısızlık boyutlarından oluşan bir sendrom olarak açıklamışlardır. Bu boyutlandırma literatürde fazlaca kabul görmüştür.

Leiter ve Maslach'a (1988) göre, aşırı iş yükünden dolayı duygusal yorgunluk yaşayan bireyde öncelikle duygusal tükenmişlik başlar. Bu iş yükünden kurtulmak amacıyla birey çevresindeki insanlardan uzaklaşmaya ve onlarla iletişim kurmamaya çalışır. Bu durum ikinci boyut olan duyarsızlaşmanın işaretidir. Duygusal olarak yorulan ve çevresindeki insanlardan uzaklaşan birey topluma katkı yapamadığını düşünerek tükenmişliğin son boyutu olan kişisel başarısızlık hissine kapılır.

Duygusal tükenme, tükenmişliğin merkezi niteliğindedir ve bu karmaşık sendromun en açık göstergesidir. Duygusal olarak tükenmiş birey, işindeki insan ilişkileri açısından kendisini sıkışmış hisseder. Duygusal tükenme aşırı iş yükünün üstesinden gelmenin bir yolu olarak kişinin işinden duygusal ve bilişsel olarak soğumasına neden olan bir durumdur. Duyarsızlaşma, kişilerin hizmet verdikleri bireylere karşı kendilerini çekici ve eşsiz kılan niteliklerini ihmal ederek onlarla aralarına mesafe koymaya çalışmalarıdır. Kişisel başarısızlık ise kişinin işine karşı kendisini negatif ve yetersiz olarak değerlendirme eğilimidir (Maslach, Schaufeli, \& Leiter, 2001, s. 403).

Pines ve Aronson'a (1988) göre tükenmiş bireyler şevk, idealizm, perspektif ve amaç kaybı yaşarlar; devamlı stres, umutsuzluk, çaresizlik ve sıkışmışlık duyguları ile fiziksel, duygusal ve zihinsel bir tükenme durumu yaşarlar. Eker, Anbar ve Karabıyık (2007) tükenmişliği, iş yaşamını etkileyen ciddi bir problem olarak görmekte ve iş doyumunu, performansı ve hizmet kalitesini olumsuz etkilediğini belirtmektedir. Çam'a (1992) göre mesleki olarak tükenmişlik yaşayan bireylerde işi bırakma niyetinde artış, hizmet kalitesinin bozulması, işi savsaklama, izin bitiminde rapor alma gibi yollarla izni uzatmaya çalışma, işte ve iş dişında insan ilişkilerinde bozulma, uyumsuzluk, işe izinsiz gelmeme, iş doyumsuzluğu, sebepsiz hastalanma eğilimleri gibi olumsuz durumlar görülebilir. Öğretmenlerin tükenmişliği, stresli öğretim koşullarına, öğrencilere, öğretme durumuna ve yönetim desteğinin eksikliğine karşı bir tepki olarak adlandırılabilir (Tümkaya, 1997). Byrne'nin (1992) organizasyonel ve kişisel faktörlerin öğretmen tükenmişliğine katkısı olup olmadığını araştırdığı çalışmasında öğretmenlerde 
tükenmişliği etkileyen organizasyonel faktörlerin; rol çatışması, fazla iş yükü, sınıf atmosferi, karar verme yetkisi ve görülen idari destek, kişisel faktörlerin ise; işgal edilen mevki, benlik saygısı ve dış denetim odağı olduğunu göstermiştir. Karakelle ve Canpolat (2008), tükenmişlik düzeyi yüksek öğretmenlerin çoğunluğunun öğrencileri tanımadığını, ders dışında öğrencileriyle vakit geçirmediğini, sınıf kontrolünü kaybetme endişesiyle ders sırasında güncel olaylara yer vermediğini ve önemli bir kısmının öğrencilerle arkadaşça bir ilişki kurmadığını belirtmiştir.

Ghorpade, Lackritz \& Singh (2007) ve Swider \& Zimmerman'in (2010) yaptıkları çalışmalarda da tükenmişliğin iş performansını doğrudan olumsuz etkilediği sonuçlarına ulaşılmıştır. Ransford, Greenberg, Domitrovich, Small ve Jacobson'ın (2009) yaptığı bir çalışmada da öğretmen tükenmişliğinin sosyo-duygusal müfredatla ilgili alternatif düşünme stratejilerinin geliştirilmesiyle negatif ilişkili olduğu bulunmuştur.

\section{Örgütsel Bağlılık ve Mesleki Tükenmişlik Arasındaki İlişki}

Alanyazın incelendiğinde örgütsel bağlılık ile mesleki tükenmişlik arasındaki ilişkiyi inceleyen birçok araştırmaya rastlanmaktadır. Hakanen, Bakker ve Schaufeli'in (2006) araştırmasında öğretmenlerin örgütsel bağlılıkları ile tükenmişlik algıları arasında negatif yönlü bir ilişki bulunmuştur. Özel'in (2009) yaptığı çalışmada akademisyenlerin örgütsel bağl1lıkları ile tükenmişlik düzeyleri arasında negatif yönlü düşük düzeyde bir ilişki belirlenmiştir. Güneş, Bayraktaroğlu ve Özen Kunatis'in (2009) bir üniversitede çalışan personeller ile yaptıkları çalışmada örgütsel bağlılık ve mesleki tükenmişlik arasında negatif yönlü bir ilişkinin olduğu sonucuna ulaş1lmıştır. Salehi ve Gholtash'in (2011) başka bir üniversitenin personelleri ile yaptıkları çalışmada da örgütsel bağlılık ve mesleki tükenmişlik arasında negatif yönlü orta düzeyde bir ilişkinin olduğu sonucuna ulaşılmıştır. Sajid'in (2014) yaptığı çalışmada ise öğretmenlerin örgütsel bağl1lıkları ve mesleki tükenmişlikleri arasında anlamlı bir ilişki kurulamamış ancak mesleki tükenmişliğin örgütsel bağlılı̆̆ı negatif etkilediği sonucuna ulaşılmıştır. Akgül'ün (2014) araştırmasında da matematik öğretmenlerin tükenmişlik algıları ile örgütsel bağl1lıkları arasında negatif yönlü düşük düzeyde ilişki olduğu ve öğretmenlerin mesleki tükenmişlik algısının örgütsel bağl1lıklarındaki toplam varyansın \%8'ini açıkladığı sonucuna ulaşılmıştır. Ancak Werang, Asmaningrum ve Irianto'nun (2015) ilkokul öğretmenleri ile yaptıkları çalışmanın sonucu, ilgili literatürdeki diğer araştırma sonuçları ile farklılık göstermekte ve öğretmenlerin örgütsel bağl1lıkları ile mesleki tükenmişlikleri arasında pozitif yönlü orta düzeyde bir ilişkinin olduğu sonucunu ortaya koymaktadır.

Bir kısmı yukarıda da verilen, literatürde rastlanan araştırmaların çoğunluğunda öğretmenlerin tükenmişlik algıları ile örgütsel bağl1lıkları arasında negatif yönlü ilişkinin olduğu sonuçları elde edilmiştir.

Yukarda sözü edilen iki değişkenin düzeylerinin öğretmenler açısından zaman içinde değişkenlik göstermesi bu değişkenlerin dinamik yapısı nedeniyle beklenen bir durumdur. Her ne kadar literatürde öğretmenlerin örgütsel bağl1lıkları ve mesleki tükenmişlik algıları ile ilgili çalışmalara fazlaca rastlansa da bu değişkenlerin öğretmenlerdeki düzeyinin ve birbirleri ile ilişkilerinin aralıklarla ölçülmesinin eğitimöğretim faaliyetlerine katkı sağlayacağı düşünülmektedir. Bu araştırmada da belirtilen iki değişken arasındaki ilişki durumu ve düzeyi ortaya konmaya çalışılmıştır. 
$\mathrm{Bu}$ araştırmanın temel amacı, ilkokul öğretmenlerinin örgütsel bağlılık alt boyutları ile mesleki tükenmişlik algıları arasındaki ilişkiyi belirlemektir. Bu amaç doğrultusunda aşağıdaki sorulara cevap aranmıştır.

1.İlkokul öğretmenlerinin örgütsel bağlılıkları ne düzeydedir?

2.İlkokul öğretmenlerinin mesleki tükenmişlik algıları ne düzeydedir?

3.İlkokul öğretmenlerinin örgütsel bağlılıkları ile mesleki tükenmişlik algıları arasında anlamlı bir ilişki var mıdır?

4.İlkokul öğretmenlerinin mesleki tükenmişlik algıları örgütsel bağlılıklarının anlamlı bir yordayıcısı mıdır?

\section{Yöntem}

$\mathrm{Bu}$ bölümde araştırmanın modeli, evren ve örneklemi, veri toplama araçları ve verilerin analizi hakkında bilgilere yer verilmiştir.

\section{Araştırmanın Modeli}

İlkokul öğretmenlerinin örgütsel bağlılıkları ile mesleki tükenmişlik algıları arasındaki ilişkiyi belirlemeyi amaçlayan bu araştırma, nicel araştırmaların genel tarama desenli araştırma türleri içerinde yer alan ilişkisel tarama deseninde bir araştırmadır.

\section{Araştırmanın Evren ve Örneklemi}

Araştırmanın evrenini 2015-2016 eğitim-öğretim yılında Bayburt ili ve ilçelerinde görev yapan toplam 331 ilkokul öğretmeni oluşturmaktadır. Araştırmada evrendeki bütün öğretmenlere ölçek gönderilmiş ve geriye dönen ölçeklerden 272'si yansız olarak alınmış ve araştırmanın veri grubunu oluşturmuştur.

\section{Veri Toplama Araçları}

Araştırma verilerinin toplanmasında Balay (2000) tarafından geliştirilen Örgütsel Bağlılık Ölçeği ile Maslach ve Jackson (1981) tarafından geliştirilen ve Ergin (1993) tarafından Türkçe’ye uyarlanan Maslach Tükenmişlik Ölçeği kullanılmıştır.

Balay (2000) tarafindan geliştirilen Örgütsel Bağlılık Ölçeği 27 madde ve üç boyuttan (Uyum, Özdeşleşme ve İçselleştirme) oluşmaktadır. Balay’a (2000) göre uyum boyutundaki bağlılık bireyin örgütsel işleri yapmak zorunda olduğu için yapmasını ifade eder. Özdeşleşme kişilerin yakın olma isteğine dayanır. İçselleştirme ise bireysel değerlerin örgütsel değerlerle uyumluluğunu ifade eder. Ölçeği oluşturan maddeler " 1 = Hiç katılmıyorum, 2 = Az katılıyorum, $3=$ Orta düzeyde katılıyorum, $4=$ Çok katılıyorum, 5 = Tam katılıyorum" şeklinde puanlanmıştır. Balay (2000) ölçekten toplam puan elde etmek yerine, boyutlar bazında değerlendirme yapılmasını önermiştir. Ölçeğin her bir boyutundan alınan puanların artması o boyuttaki örgütsel bağlılığın da arttığı anlamına gelmektedir. Balay (2000) tarafindan ölçeğin alt boyutlarına ait Cronbach Alfa değerleri "Uyum: ,79; Özdeşleşme: ,89; İçselleştirme: 93" olarak belirlenmiştir. Bu araştırmada ise ölçeğin alt boyutlarına ilişkin Cronbach Alfa değerleri sırasılla .71; .84; ve .87 olarak belirlenmiştir.

Maslach ve Jackson (1981) tarafindan geliştirilen ve Ergin (1993) tarafindan Türkçe'ye uyarlanan Maslach Tükenmişlik Ölçeği 22 madde ve üç boyuttan (Duygusal Tükenme, Duyarsızlaşma, Kişisel Başarısızlık) oluşmaktadır. "Duygusal Tükenme” ve 
"Duyarsızlaşma" boyutlarını oluşturan maddeler; "1=Hiçbir zaman, 2=Çok az, 3=Bazen, 4=Çoğu zaman, 5=Her zaman" şeklinde, "Kişisel Başarısızlık" boyutunu oluşturan maddeler ise olumlu ifadeler içerdiğinden ters puanlama yapılarak " $1=$ Her zaman, 2=Çoğu zaman, 3=Bazen, 4=Çok az, 5=Hiçbir zaman" şeklinde puanlanmıştır. $\mathrm{Bu}$ nedenle ölçekten alınan puanların artması tükenmişliğin de arttığı anlamına gelmektedir. Ergin (1993) tarafından ölçeğin alt boyutlarına ait Cronbach Alfa değerleri "Duygusal Tükenme: .83; Duyarsızlaşma; .71; Kişisel Başarısızlık: .72” olarak belirlenmiştir. $\mathrm{Bu}$ araştırmada ise ölçeğin alt boyutlarına ait Cronbach Alfa değerleri sırasıyla .81; .70; ve .82 olarak belirlenmiştir.

Örgütsel bağlılık ölçeğinde ve tükenmişlik ölçeğinde aritmetik ortalamalara karşılık gelen tanımlamalar ve düzeyler Tablo 1'de verilmiştir.

Tablo 1

Örgütsel Bă̆lllık ve Mesleki Tükenmişlik Ölçeğinde Aritmetik Ortsalamalara Karşılık Gelen Düzeyler

\begin{tabular}{cccc}
\hline $\begin{array}{c}\text { Aritmetik } \\
\text { Ortalama }\end{array}$ & Örgütsel Bağllık Ölçeğine İlişkin & $\begin{array}{c}\text { Mesleki Bağlllı Ölçeğine İlişkin } \\
\text { Tanımlama }\end{array}$ & Düzey \\
\hline $1.0-1.79$ & Hiç katıllmıyorum & Hiçbir zaman & Düşük \\
$1.80-2.59$ & Az katılıyorum & Çok az & Düşük \\
$2.60-3.39$ & Orta düzeyde katılıyorum & Bazen & Orta \\
3.40 ve 4.19 & Çok katıllyorum & Çoğu zaman & Yüksek \\
4.20 ve 5.00 & Tam katıllyorum & Her zaman & Yüksek \\
\hline
\end{tabular}

\section{Verilerin Analizi}

Araştırma verilerinin analizinde SPSS 21 paket programı kullanılmıştır. Değişkenler arasındaki ilişkinin belirlenmesi için öncelikle verilerin normallik dağılımları kontrol edilmiştir. Bunun için verilerin basıklık çarpıklık değerleri, varyasyon katsayıları, histogramları ve Q-Q grafikleri incelenmiştir. Ayrıca basit doğrusal regrasyon analizi için ön koşullardan biri olan iki değişkenli normallik varsayımı için de değişken çiftlerinin saçılma diyagramları incelenmiştir ve verilerin normal dağıldıklarına karar verilmiştir. Araştırma verilerinin analizinde aritmetik ortalama ve standart sapma gibi basit istatistiki yöntemler ile Pearson korelasyon analizi ve basit doğrusal regresyon analizi istatistiki yöntemleri kullanılmıştır. Verilerin analizinde kullanılan korelasyon analizi ilişki katsayılarına karşılık gelen düzeyler Tablo 2'de verilmiştir. 
Tablo 2

Korelasyon Analizi İlişki Katsayıları ve Düzeyi

\begin{tabular}{cc}
\hline Korelasyon Katsayısı & İlişki Düzeyi \\
\hline $.00-.30$ & Düşük \\
$.31-.70$ & Orta \\
$.71-.89$ & Yüksek \\
$.90-1.00$ & Çok Yüksek \\
\hline
\end{tabular}

(Kaynak: Büyüköztürk, 2012)

\section{Bulgular}

$\mathrm{Bu}$ bölümde, araştırmada elde edilen bulgular araştırmanın alt amaçlarına göre başlıklandırılarak verilmiştir.

\section{İlkokul Öğretmenlerinin Örgütsel Bağlılık Düzeylerine İlişkin Bulgular}

İlkokul öğretmenlerinin örgütsel bağlılık düzeylerine ilişkin aritmetik ortalama ve standart sapma değerleri Tablo 3 'te verilmiştir.

Tablo 3

İlkokul Öğretmenlerinin Alt Boyutlara Göre Örgütsel Bă̆lılık Düzeyleri

\begin{tabular}{lll}
\hline Boyutlar & $\overline{\mathrm{X}}$ & Ss \\
\hline Uyum & 1.48 & 2.18 \\
Özdeşleşrme & 3.66 & 3.99 \\
İçselleştirme & 3.81 & 3.43
\end{tabular}

Tablo 3'te de görüldüğü gibi ilkokul öğretmenlerinin örgütsel bağl1lıklarının uyum alt boyutunda düşük düzeyde $(\overline{\mathrm{X}}=1.48)$, özdeşleşme ve içselleştirme alt boyutlarında ise yüksek düzeyde $(\overline{\mathrm{X}}=3.66 ; \overline{\mathrm{X}}=3.81)$ olduğu belirlenmiştir.

\section{İlkokul Öğretmenlerinin Mesleki Tükenmişlik Algılarına İlişkin Bulgular}

İlkokul öğretmenlerinin mesleki tükenmişlik algılarına ilişkin aritmetik ortalama ve standart sapma değerleri Tablo 4'te verilmiştir.

Tablo 4

İlkokul Öğretmenlerinin Mesleki Tükenmişlik Algıları

\begin{tabular}{lll}
\hline Boyutlar & $\overline{\mathrm{X}}$ & \multicolumn{1}{c}{$S s$} \\
\hline Duygusal Tükenme & 1.96 & 2.94 \\
Duyarsızlaşma & 1.29 & 1.78 \\
Kişisel Başarısızlık & 2.00 & 3.26 \\
\hline Toplam Tükenmişlik & 1.82 & 4.12 \\
\hline
\end{tabular}


Tablo 4'te de görüldüğü gibi ilkokul öğretmenlerinin toplam mesleki tükenmişlik algılarında ve duygusal tükenme, duyarsızlaşma, kişisel başarısızlık alt boyutlarında düşük düzeyde $(\overline{\mathrm{X}}=1.96 ; \overline{\mathrm{X}}=1.29 ; \overline{\mathrm{X}}=1.20 ; \overline{\mathrm{X}}=1.82$ ) mesleki tükenmişlik algısına sahip oldukları belirlenmiştir. Bu bulgular ilkokul öğretmenleri için olumlu sonuçlar olarak değerlendirilebilir.

\section{İlkokul Öğretmenlerinin Örgütsel Bağlılık Alt Boyutları ile Mesleki Tükenmişlik Algıları Arasındaki İlişkiye İlişkin Bulgular}

İlkokul öğretmenlerinin örgütsel bağlılık alt boyutları ile mesleki tükenmişlik algıları arasındaki ilişkiye ilişkin bulgular Tablo 5 'te verilmiştir.

Tablo 5

İlkokul Öğretmenlerinin Örgütsel Băglllıkları ile Mesleki Tükenmişlik Algıları Boyutları Arasındaki İlişki

\begin{tabular}{lllllll}
\hline & 1 & 2 & 3 & 4 & 5 & 6 \\
\hline Uyum & 1 & & & & & \\
Özdeşleşme & $-.348^{* *}$ & 1 & & & & \\
İçselleştirme & $-.345^{* *}$ & $.600^{* *}$ & 1 & & & \\
Duygusal Tükenme & $.265^{* *}$ & $-.186^{* *}$ & $-.259^{* *}$ & 1 & & \\
Duyarsızlaşma & $.378^{* *}$ & $-.211^{* *}$ & $-.146^{*}$ & $.587^{* *}$ & 1 & \\
Kişisel Başarısızlık & $.306^{* *}$ & $-.287^{* *}$ & $-.618^{* *}$ & $.439^{* *}$ & $.246^{* *}$ & 1 \\
\hline $\begin{array}{l}\text { Toplam Mesleki } \\
\text { Tükenmişlik }\end{array}$ & $.377^{* *}$ & $-.271^{* *}$ & $-.461^{* *}$ & $.850^{* *}$ & $.622^{* *}$ & $.772^{* *}$ \\
\hline \multicolumn{1}{c}{$* * 0<0.01$} & $* p<0.05$ & & & & & \\
\end{tabular}

İlkokul öğretmenlerinin örgütsel bağlılık alt boyutları ile mesleki tükenmişlik algıları arasında anlamlı bir ilişki olup olmadığını belirlemek için yapılan Pearson korelasyon analizi sonucunda örgütsel bağl1lı̆̆ı uyum alt boyutu ile mesleki tükenmişliğin duygusal tükenme alt boyutu arasında pozitif yönlü, düşük düzeyde ve anlamlı bir ilişki $(r=.265, p<0.01)$, diğer alt boyutlar ve toplam mesleki tükenmişlik arasında ise pozitif yönlü orta düzeyde bir ilişki bulunmuştur $(r=.378, p<0.01 ; r=$ $.306, p<0.01 ; r=.377, p<0.01)$. Bu bulgular, ilkokul öğretmenlerinin uyum boyutuyla ilgili bağlılıkları attıkça mesleki tükenmişliklerinin de artacağ

Örgütsel bağlılığın özdeşleşme alt boyutu ile mesleki tükenmişliğin bütün alt boyutları ve toplam mesleki tükenmişlik arasında negatif yönlü, düşük düzeyde, anlamlı bir ilişki bulunmuştur $(r=-.186, p<0.01 ; r=-.211, p<0.01 ; r=-.287, p<0.01 ; r=-$ $.271, p<0.01)$. Bu bulgular, ilkokul öğretmenlerinin özdeşleşme boyutuyla ilgili bağlılıkları attıkça mesleki tükenmişliklerinin de azalacağı şeklinde yorumlanabilir.

Örgütsel bağlılığın içselleştirme alt boyutu ile toplam mesleki tükenmişlik ve kişisel başarısızlık alt boyutu arasında negatif yönlü, orta düzeyde, anlamlı bir ilişki ( $r=$ -.461, $p<0.01 ; r=-, 618, p<0.01)$; içselleştirme alt boyutu ile mesleki tükenmişliğin 
duygusal tükenme ve duyarsızlaşma alt boyutları arasında ise negatif yönlü, düşük düzeyde, anlamlı bir ilişki bulunmuştur ( $r=-.259, p<0.01 ; r=-.146, p<0.05)$. Bu bulgular, ilkokul öğretmenlerinin içselleştirme boyutuyla ilgili bağl1lıkları attıkça mesleki tükenmişliklerinin de azalacağı şeklinde yorumlanabilir.

\section{İlkokul Öğretmenlerinin Mesleki Tükenmişlik Algılarının Örgütsel Bağlılık Düzeylerini Yordamasına İlişkin Bulgular}

İlkokul öğretmenlerinin mesleki tükenmişlik algılarının örgütsel bağlılık düzeylerini yordamasına ilişkin bulgular Tablo 6'da verilmiştir.

Tablo 6

İlkokul Öğretmenlerinin Mesleki Tükenmişlik Algllarının Örgütsel Bağlılık Düzeylerini Yordamasına İlişkin Basit Doğrusal Regresyon Analizi Sonuçları

\begin{tabular}{|c|c|c|c|c|c|}
\hline & $B$ & Std. Hata & $\beta$ & $t$ & $p$ \\
\hline Sabit & 7.865 & .905 & & 8.688 & .000 \\
\hline Mesleki Tükenmişlik & .199 & .022 & .265 & 4.512 & .000 \\
\hline \multicolumn{6}{|c|}{ Yordanan Değişken: Uyum; $\mathrm{R}^{2}=.07 ; \mathrm{F}=20.355 ; \mathrm{p}=.00$} \\
\hline Sabit & 37.095 & 1.654 & & 22.429 & .000 \\
\hline Mesleki Tükenmişlik & -.193 & .040 & -.280 & -4.794 & .000 \\
\hline \multicolumn{6}{|c|}{ Yordanan Değişken: Özdeşleşme; $\mathrm{R}^{2}=.07 ; \mathrm{F}=22.985 ; \mathrm{p}=.00$} \\
\hline Sabit & 53.880 & 1.837 & & 29.338 & .000 \\
\hline Mesleki Tükenmişlik & -.296 & .045 & -.374 & -6.625 & .000 \\
\hline
\end{tabular}

Yordanan Değişken: İçselleştirme; $\mathrm{R}^{2}=.14 ; \mathrm{F}=43.890 ; p=.00$

Tablo 6 incelendiğinde, örgütsel bağl1lığın her üç boyutu için de regresyon işleminde kullanılan modelin istatistiksel olarak anlamı olduğu ( $F$ Uyum $=20.355$; $p<.01$; F Özdeşleşme $=22.985 ; p<.01$; F İçselleştirme $=43.890 ; p<.01)$ görülmektedir. Buna göre yordayan değişken yordama işlemini model üzerinde başarılı bir şekilde yerine getirmiştir. Basit doğrusal regresyon analizi sonucunda standardize edilmiş ( $\beta$ ) katsayısı ve $t$ değerleri incelendiğinde ilkokul öğretmenlerinin mesleki tükenmişliklerinin, örgütsel bağlılıklarının bütün boyutlarının anlamlı bir yordayıcısı olduğu (R Uyum = -.26; $\mathrm{R}^{2}$ Uyum $=.07 ; p<.01 ; \mathrm{R}$ Özdeşleşme = $-.28 ; \mathrm{R}^{2}$ Özdeşleşme = $.07 ; p<.01 ; \mathrm{R}$ İçselleştirme $=.37 ; \mathrm{R}^{2}$ İçselleştirme $\left.=.14 ; p<.01\right)$ bulunmuştur. Buna göre ilkokul öğretmenlerinin mesleki tükenmişlik alg1sı ilkokul öğretmenlerinin örgütsel bağl11ıklarının uyum boyutundaki toplam varyansın \%7'sini, özdeşleşme boyutundaki toplam varyansın \%7'sini, içselleştirme boyutundaki toplam varyansın ise \%14'ünü açıklamaktadır. Yine Tablo 4'e göre mesleki tükenmişlikteki 1 birimlik artışın örgütsel bağlılı̆̆ın uyum boyutunda .099 birimlik artışa; 1 birimlik azalmanın ise özdeşleşme boyutunda .193 birimlik azalmaya $(B=-.193 ; t=-4.794)$; içselleştirme boyutunda da .296 birimlik azalmaya $(B=-.296 ; t=-6.625)$ sebep olacağ 1 söylenebilir. 


\section{Sonuç, Tartışma ve Öneriler}

İlkokul öğretmenlerinin örgütsel bağlılıkları ile mesleki tükenmişlik algıları arasındaki ilişkiyi belirlemeyi amaçlayan bu araştırmada ilkokul öğretmenlerinin örgütsel bağl1lıklarının uyum alt boyutunda düşük düzeyde, özdeşleşme ve içselleştirme alt boyutlarında ise yüksek düzeyde olduğu sunucuna ulaşılmıştır. Örgütsel bağglılı̆ın, uyum alt boyutunda düşük, diğer boyutlarda yüksek olması ilkokul öğretmenleri için olumlu bir durumdur. Uyum alt boyutundaki bağlllı̆̆ın düşüklüğü ilkokul öğretmenlerinin örgüte ödül kazanmak ya da cezadan kaçınmak için bağlanmadıklarının göstergesi sayllabilir (Brockner, Tyler, \& Cooper-Schneider, 1992, s. 244). Diğer boyutlarda bağlılı̆̆ın yüksek olması ise ilkokul öğretmenlerinin okullarının üyesi olmaktan gurur duydukları, okullarının değerlerine saygı gösterdikleri ve okulların ve kendilerinin değerlerinin benzer olduğu şeklinde yorumlanabilir. Erdaş (2009), Y1lmaz Koca (2009) ve Sezer'in (2005) araştırmalarında da bu araştırmayla benzer olarak öğretmenlerin en fazla içselleştirme boyutunda, en az uyum boyutunda örgüte bağlandıkları sonucuna ulaşılmıştır.

Duran (2014) ve Kaygısız'ın (2012) ilköğretim öğretmenleri ile; Hamid, Nordin, Adnan ve Sirun (2013), Nordin, Rashid, Ghani, Aripin ve Darus (2010) ve Dee, Henkin ve Singleton'un (2006) ise ilkokul öğretmenleri ile yaptıkları araştırmalarda; öğretmenlerin örgütsel bağl1lık düzeyleri orta düzeyde bulunmuştur. İmamoğlu (2011), Sarıkaya (2011) ve Uğurlu'nun (2009) araştırmasında ise ilköğretim öğretmenlerinin örgütsel bağl1l1k düzeyleri yüksek düzeyde bulunmuştur.

Araştırmada ilkokul öğretmenlerinin toplam mesleki tükenmişlik algılarında ve bütün alt boyutlarında (duygusal tükenme, duyarsızlaşma ve kişisel başarısızlık) düşük düzeyde mesleki tükenmiş̧lik algısına sahip oldukları sonucuna ulaşılmıştır. Bu sonuç ilkokul öğretmenlerinin işlerine karşı duygusal ve bilişsel olarak bir soğukluk hissetmedikleri, öğrencilerine karşı ilgisiz davranmadıkları ve işlerinde kendilerini yeterli hissettikleri şeklinde yorumlanabilir (Maslach, Schaufeli ve Leiter, 2001). Akyüz ve Kaya'nın (2014) araştırmasında da ilköğretim okullarında çalışan öğretmenlerin genel tükenmişlik algıları ile duygusal tükenmişlik ve duyarsızlaşma boyutundaki tükenmişlik algılarının düşük olduğu; bu araştırmadan farklı olarak kişisel başarısızlık boyutundaki tükenmişlik algılarının yüksek olduğu sonucuna ulaşılmıştır. Demir ve Kara'nın (2014) araştırmasında ise ilkokul birinci sınıf öğretmenlerinin tükenmişlik düzeylerinin orta düzeyde olduğu ve yüksek düzeye çok yakın olduğu sonucuna ulaşı1mıştır. Yılmaz, Altınkurt, Güner ve Şen (2015) ile Yıılmaz'ın (2014) araştırmasında ise öğretmenlerin kişisel başarısızlık ve duyarsızlaşma boyutlarında bu çalışmayla benzer olarak düşük düzeyde tükenmişliğe sahip oldukları ancak duygusal tükenme boyutunda bu çalışmadan farklı olarak orta düzeyde tükenmişliğe sahip oldukları sonucuna ulaşılmıştır. Ergül, Saygın ve Tösten'in (2013) araştırmasında sınıf öğretmenlerinin bu çalışmadan farklı olarak orta düzeyde tükenmişliğe sahip olduğu sonucuna ulaşılmıştır. İnce ve Şahin'in (2016) araştırmasında ise sınıf öğretmenlerinin çoğunluğunun duygusal tükenme boyutunda yüksek düzeyde tükenmişlik hissettikleri sonucuna ulaşılmıştır.

Araştırmada örgütsel bağlılığın uyum alt boyutu ile mesleki tükenmişliğin bütün alt boyutları ve toplam mesleki tükenmişlik arasında pozitif yönlü bir ilişki bulunmuş; bu ilişkinin duygusal tükenme alt boyutunda düşük düzeyde, diğer boyutlarda (duyarsızlaşma, kişisel başarısızlık) ve toplam mesleki tükenmişlikte ise orta düzeyde 
olduğu belirlenmiştir. $\mathrm{Bu}$ sonuç, okullarına ödül alma ve cezadan kaçınma amacıyla bağlılık gösteren ilkokul öğretmenlerinin mesleki tükenmişliklerinin artacağı şeklinde yorumlanabilir. Örgütsel bağlılığın özdeşleşme alt boyutu ile mesleki tükenmişliğin bütün alt boyutları ve toplam mesleki tükenmişlik arasında negatif yönlü, düşük düzeyde, anlamlı bir ilişki bulunmuştur. Bu sonuç, okullarının değerlerine saygı duyan ve bu değerler için çalışmaktan gurur duyan ilkokul öğretmenlerinin mesleki tükenmişliklerinin azalacağ 1 şeklinde yorumlanabilir. Örgütsel bağlılığın içselleştirme alt boyutu ile mesleki tükenmişliğin duygusal tükenme ve duyarsızlaşma alt boyutları arasında negatif yönlü, düşük düzeyde, anlamlı bir ilişki, örgütsel bağlılığın içselleştirme alt boyutu ile mesleki tükenmişliğin kişisel başarısızlık alt boyutu ve toplam mesleki tükenmişlik arasında ise negatif yönlü, orta düzeyde, anlamlı bir ilişki bulunmuştur. $\mathrm{Bu}$ sonuç, ilkokul öğretmenlerinin kendi değerleri ile okulun değerleri örtüşürse ve elde ettikleri başarılarla topluma katkı yaptıklarını hissederlerse mesleki tükenmişliklerinin de azalacağı şeklinde yorumlanabilir. Hakanen, Bakker ve Schaufeli'in (2006) ve Akgül'ün (2014) araştırmasında da öğretmenlerin örgütsel bağl1lıkları ile tükenmişlik algıları arasında negatif yönlü düşük düzeyde ilişki bulunmuştur. Bu sonuçlardan hareketle; ilkokulların amaçları belirlenirken, değerleri oluşturulurken öğretmenlerin de görüşlerini alarak onların kendi değerleri ile okulun değerlerini benzer hale getirmelerine olanak sağlamak; bir takım ruhu oluşturarak örgütün başarılarından gurur duymalarını sağlamak; öğretmenlere, kendilerini başarılı kılacakları etkinliklerle okul örgütüne ve topluma katkı sağlayacakları imkânlar tanımak onların özdeşleşme ve içselleştirme bağlılıklarının arttırılması ve mesleki tükenmişliklerinin azaltılması için önerilebilir. Werang, Asmaningrum ve Irianto'nun (2015) ilkokul öğretmenleri ile yaptıkları çalışmada yukarıdaki çalışmalardan farklı olarak öğretmenlerin örgütsel bağlılıkları ile mesleki tükenmişlikleri arasında pozitif yönlü orta düzeyde bir ilişki olduğu bulunmuştur.

Araştırmada elde edilen bir diğer sonuç da ilkokul öğretmenlerinin mesleki tükenmişlik algısının örgütsel bağlılığın bütün alt boyutlarının anlamlı bir yordayıcısı olduğu; uyum ve özdeşleşme alt boyutlarındaki toplam varyansın \%7'sini, içselleştirme alt boyutundaki toplam varyansın ise \%14'ünü açıkladığı şeklindedir. Akgül'ün (2014) araştırmasında da ilkokul öğretmenlerinin mesleki tükenmişlik algısının ilkokul öğretmenlerinin örgütsel bağlılıklarındaki toplam varyansın \%8'ini açıkladığ sonucuna ulaşılmıştır. Bu oranlar çok yüksek olmamakla birlikte mesleki tükenmişliğin örgütsel bağl1lıktaki değişkenlikte yerinin olduğu şeklinde yorumlanabilir. Çetin, Basım ve Aydoğan'ın (2011) çalışmasında ise örgütsel bağlılık duygusal bağlılık, devam bağlılı̆̆1 ve normatif bağlılık olarak ele alaınmış ve üç bağlılık türünün de duygusal tükenmenin yordayıcıları olduklarını ortaya konmuştur. Bununla birlikte, duygusal bağlılık ve normatif bağl1lı, duygusal tükenme üzerinde negatif bir etki yaparken; devam bağlılığının duygusal tükenme üzerinde pozitif bir etkisinin olduğu sonucuna ulaşılmıştır. $\mathrm{Bu}$ sonuçlardan hareketle; ilkokul öğretmenlerinin özdeşleşme ve içselleştirme boyutlarındaki örgütsel bağlılıklarının arttırılması için öncelikle ilkokul öğretmenlerinin mesleki tükenmişliklerine neden olan faktörlerin belirlenmesi ve bu faktörlerin ortadan kaldırılması için de çalışmaların yapılması araştırmacılara ve yöneticilere önerilebilir. 


\section{Summary}

Purpose and Significance: The relationship between organizational commitment subdimention and professional burnout perception constitutes the problem of this study. The aim of this research is to determine the relationship between organizational commitment sub-dimentions and professional burnout perception of elementary teachers. It is thought that measuring the level of these variables in teachers and their interactions with each other will contribute to the educational activities.

Method: This research is relational screening model that fall into general screening model of quantitatives research. The population of research constitutes 331 elementary teachers who works in province and districts of Bayburt in the acdemic year 2015-2016. The surveys were sent to all of elementary teachers in the population. Returning of the surveys 272 constitutes data group of research. Research data has been collected with Organizational Commitment Scale that was developed by Balay (2000) and Maslach Burnout Scale that was developed by Maslach and Jackson (1981) and adapted to Turkish by Engin (1992). In the analysis of research data was used simple statistical methods as arithmetic mean and standart deviation with Pearson correlation analysis and simple linear regression analysis statistical methods.

Results: According to the researches organization commitment of elementary teachers is low level $(\overline{\mathrm{X}}=1.48)$ in complience sub-dimention but high level $(\overline{\mathrm{X}}=3.66 ; \overline{\mathrm{X}}=3.81)$ in Identification sub-dimention and Internalization sub-dimention. It's determined that elementary teachers have low level $(\bar{X}=1.96 ; \bar{X}=1.29 ; \bar{X}=1.200 ; \bar{X}=1.82)$ perception of professional burnout in total perception of professional burnout and emotional burnout, depersolination, personal failure sub-dimentions.

It has been found that there is positive oriented, low level and significant relationship between complience sub-dimention of organization commitment and emotional bornout sub-dimention of professional burnout $(r=.265, p<0.01)$ but there is positive oriented, middle level relationsips between other sub-dimentions and total professional burnout $(r$ $=.378, p<0.01 ; r=.306, p<0.01 ; r=.377, p<0.01)$. It has been found that there is negative oriented, low level and significant relationship between Identification subdimention of organization commitment and all sub-dimentions of professional burnout $(r=-.186, p<0.01 ; r=-.211, p<0.01 ; r=-.287, p<0.01 ; r=-.271, p<0.01)$. It has been found that there is negative oriented, middle level and significant relationship between Internalization sub-dimention of organizational commitment with total professional burnout and its personel failure sub-dimention $(r=-.461, p<0.01 ; r=-$ $.618, p<0.01)$. Besides that there is negative oriented, low level and significant relationship between Internalization sub-dimention with emotional burnout and depersonalization sub-dimentions of professional burnout $(r=-.259, p<0.01 ; r=-.146$, $p<0.05)$.

According to the research results professional burnout of elementary teachers predict significantly all sub-dimentions of organization commitment $\left(\mathrm{R}\right.$ Complience $=-.26 ; \mathrm{R}^{2}$ Complience $=.07 ; p<.01 ; \mathrm{R}$ Identification $=-.28 ; \mathrm{R}^{2}$ Identification $=.07 ; p<.01 ; \mathrm{R}$ Internalization $=.37 ; \mathrm{R}^{2}$ Internalization $\left.=.14 ; p<.01\right)$. 
Discussion and Conclusion: Organizational commitment is low level in complience sub-dimention and high level in other sub-dimentions. This create a positive stuation. In complience sub-dimention low level commitment can accept that elementary teachers haven't connected to organization for win a prize or get away scot-free. In other subdimentions high commitment can be interpreted that pround of belong to schools of elementary teachers, respect to values of their schools, values of schools and own is similar. In researchs of Erdas (2009), Y1lmaz Koca (2009) and Sezer (2005) have been found similar conclusions.

In this research it has been concluded that elementary teachers have low level perception of professional burnout in total and all sub-dimentions. This conclusion can be interpreted that elementary teachers don't take against to their professions as emotional and cognitive furthermore they don't turn a cold shoulder against to students (Maslach, Schaufeli, \& Leiter, 2001, p. 403). In research of Akyuz and Kaya (2014) it has been concluded that teachers who works in elementary schools have low level perception of burnout in emotional burnout sub-dimention, deporsonalization subdimention and perception of total burnout but teachers have high level perception of burnout as different from this research in personal failure sub-dimention.

In the research it has been found that there is positive oriented relationship between all sub-dimention of professional burnout and total professional burnout with complience sub-dimention of organizational commitment. This relation is low level in emotional burnout sub-dimention but it is middle level in orther sub-dimentions (deporsonalization and personal failure) and total professional burnout. This conclusion can be interpreted that professional burnout of elementary teachers who show commitment for receive award and beat a charge can increase.

In the researce it has been found that there is negative oriented, low level and significant relationship between all sub-dimentions of professional burnout and total professional burnout with Identification sub-dimention of organizational commitment. This conclusion can be interprated that professional burnout of elementary teachers who respect to values of their schools and pride than labour for this volue can decrease.

It has been found that there is negative oriented, low level, significant relationship between emotional burnout and depersonalization sub-dimentions of professional burnout with Internalization sub-dimention of organizational commitment also there is negative oriented, middle level, significant relationship between personal failure subdimention of professional burnout and total professional burnout with Internalization sub-dimention of organizational commitment. This conclusion can be interprated that if values of elementary teachers tally with school's values and if they perceive that contribute to society due to own successes decrease professional burnout of elementary teachers. Congruently Hakanen, Bakker and Schaufeli (2006) and Akgul (2014) found negative oriented, low level relationship between organizational commitment and burnout perception of teachers.

Also, in the research it has been found that professional burnout perception of elementery teachers is a significant predictor on all sub-dimention of organization commitment. It explain 7 percent of total variance in compliance and Identification subdimentions; 14 percent of total variance in Internalization sub-dimenion. In research of Akgul (2014) has been found that professional burnout perception of elementery 
teachers explain 8 percent of total variance in organization commitment of elementary teachers. This rates can be interpreted that professional burnout have a position in variability of organization commitment associated with not to be very high. 


\section{Kaynaklar}

Akgül, Z. (2014). Örgütsel bağlllık ve tükenmişlik arasındaki ilişkinin matematik ögretmenlerinin algılarına göre incelenmesi (Yayımlanmamış Yüksek Lisans Tezi). Cumhuriyet Üniversitesi, Eğitim Bilimleri Enstitüsü, Sivas.

Balay, R. (2000). Özel ve resmi liselerde yönetici ve ögretmenlerin örgütsel bă̆lllı̆̆ (Ankara ili örneği) (Yayımlanmamış Doktora Tezi). Ankara Üniversitesi, Sosyal Bilimler Enstitüsü, Ankara.

Balay, R. (2012). Effect of learning organization perception to the organizational commitment: A comparison between private and public university. Educational Sciences: Theory \& Practice, 12(4), 2474-2486.

Becker, T. E., Meyer, J. P., \& Vandenberghe, C. (2004). Employee commitment and motivation: A conceptual analysis and integrative model. Journal of Applied Psychology, 89(6), 991-1007.

Brockner, J., Tyler, T.R., \& Cooper-Schneider, R. (1992). The influence of prior commitment to an institution on reactions to perceived unfairness: The higher they are, the harder they fall. Administrative Science Quarterly, 37, 241-261.

Büyüköztürk, Ş. (2012). Sosyal bilimler için veri analizi el kitabı (16. baskı). Ankara: Pegem Akademi Yayınları.

Byrne, B. M. (1992). Investigating causal links to burnout for elementary, intermediate, and secondary teachers. American Educational Research Association Annual Meeting, San Francisco.

Chow, I. H. S. (1994). Organizational commitment and career development of Chinese managers in Hong Kong and Taiwan. The International Journal of Career Management, 6(4), 3-9.

Çam, O. (1992). Tükenmişlik envanterinin geçerlik ve güvenirliğinin araştırılması. R. Bayraktar \& İ. Dağ (Ed.), VII. Ulusal Psikoloji Kongresi Bilimsel Çalışmaları, 2225 Eylül 1992, Ankara: Hacettepe Üniversitesi.

Çetin, F., Basim, H. N., \& Aydoğan, O. (2011). Örgütsel bağlılığın tükenmişlik ile ilişkisi: Öğretmenler üzerine bir araştırma. Selçuk Üniversitesi Sosyal Bilimler Enstitüsü Dergisi, (25), 61-70.

Dee, J., Henkin, A. B., \& Singleton, C. A. (2006). Organizational commitment of teachers in urban schools (Examining the effects of team structures). Urban Education, 41(6), 603-627.

Duran, A. D. (2014). Sınıf ögrretmenlerinin örgütsel bağlılıklart ile iş doyumları arasındaki ilişki (Yayımlanmamış Yüksek Lisans Tezi), Abant İzzet Baysal Üniversitesi, Eğitim Bilimleri Enstitüsü, Bolu.

Eker, M., Anbar, A., \& Karabıyık, L. (2007). The relationship between demographic characteristics and burnout among academicians in Turkey. Akademik Araştırmalar Dergisi, 34, 14-35.

Erdaş, Y. (2009). Denizli il merkezindeki ilköğretim ögrretmenlerinin örgütsel bă̆lılık düzeyleri (Yayımlanmamış Yüksek Lisans Tezi), Pamukkale Üniversitesi, Sosyal Bilimler Enstitüsü, Denizli. 
Ergin, C. (1993). Doktor ve hemşirelerde tükenmişlik ve Maslach Tükenmişlik Ölçeğinin uyarlanması. Rüveyde Bayraktar ve İhsan Dağ (Ed.), VII. Ulusal Psikoloji Kongresi Bilimsel Çalışmaları içinde (ss. 143-154). Ankara: VII. Ulusal Psikoloji Kongresi Düzenleme Kurulu ve Türk Psikologlar Derneği.

Ergül, H. F., Saygın, S., \& Tösten, R. (2013). Sınıf öğretmenlerinin tükenmişlik düzeylerinin çeşitli değişkenler açısından incelenmesi. Dicle Üniversitesi Sosyal Bilimler Enstitüsü Dergisi, 5(10), 266-285.

Freudenberger, H. J. (1974), Staffburn-out. Journal of Social Issues, 30(1), 159- 165.

Ghorpade, J., Lackritz, J., \& Singh, G. (2007). Burn out and personality: Evidence from academia. Journal of Career Assessment, 15, 240-256.

Güneş, İ., Bayraktaroğlu, S., \& Özen Kunatis, R. (2009). Çalışanların örgütsel bağlılık ve tükenmişlik düzeyleri arasındaki ilişki: Bir devlet üniversitesi örneği. Süleyman Demirel Üniversitesi İktisadi ve İdari Bilimler Fakültesi Dergisi, 14(3), 481-497.

Hakanen, J. J., Bakkerb, A. B., Schaufeli, W. B. (2006). Burnout and work engagement among teachers. Journal of School Psychology, 43(6), 495 - 513.

Hamid, S. F., Nordin, N., Adnan, A. A., \& Sirun, N. (2013). A study on primary school teachers' organizational commitment and psychological empowerment in the district of Klang. Procedia - Social and Behavioral Sciences, 90, 782-787.

İmamoğlu, G. (2011). Illköğretim okulu öğretmenlerinin örgütsel bă̆lllık düzeyleri ve örgütsel adalet algıları arasındaki ilişki (Yayımlanmamış Yüksek Lisans Tezi), Gazi Üniversitesi, Eğitim Bilimleri Enstitüsü, Ankara.

İnce, N. B., \& Şahin, A. E. (2016). Birleştirilmiş ve bağımsız sınıflarda çalışan sınıf öğretmenlerinin mesleki doyum ve tükenmişlik düzeylerinin karşılaştırılması. Hacettepe Üniversitesi Ĕgitim Fakültesi Dergisi, 31(2), 391-409.

Karakelle, S., \& Canpolat, S. (2008). Tükenmişlik düzeyi yüksek ilköğretim öğretmenlerinin öğrencilere yaklaşım biçimlerinin incelenmesi. Ĕ̌itim ve Bilim, 33(147), 106-120.

Katz, D., \& Kahn, R. L. (1977). Örgütlerin toplumsal psikolojisi (Çev: H. Can, Y. Bayar). Ankara: Türkiye Ortadoğu Amme İdaresi Enstitüsü Yayınları.

Kaygısız, A. G. (2012). İlköğretim öğretmenlerinin örgütsel bağlllı düzeyleri ve karara katılma durumları arasındaki ilişki (Yayımlanmamış Yüksek Lisans Tezi), Eskişehir Osmangazi Üniversitesi, Eğitim Bilimleri Enstitüsü, Eskişehir.

Leiter, M. P., \& Maslach, C. (1988). The impact of interpersonal environment of burnout and organizational commitment. Journal of Organizational Behavior, 9, 297-308.

Maslach, C., \& Jacson, S. E. (1981). The measurement of experienced burnout. Journal of Organizational Behavior, 2(2), 99-113.

Maslach, C., Schaufeli, W. B., \& Leiter, M. P. (2001). Job burnout. Annual Review of Psychology, 52, 397-422.

Meyer, J. P., \& Allen, N. J. (1991). A three-component conceptualization of organizational commitment. Human Resource Management Review, 1(1), 61-89.

Meyer, J. P., \& Allen, N. J. (1997). Commitment in the workplace, theory research and application. Thousand Oaks, CA: Sage Publications, Inc. 
Mosheti, P. A. (2013). Teacher participation in school decision-making and jobsatisfaction as correlates of organizational commitment in seniorschools in Botswana (Unpublished Doctoral Dissertation), Andrews University, Michigan, ABD.

Mowday, R. T., Porter, L. W., \& Steers, R. (1982). Employee-organization linkages: The psychology of commitment, absenteeism, and turnover. New York: Academic Press.

Nordin, F., Rashid, R. M., Ghani, R., Aripin, R., \& Darus, Z. (2010). Teacher professionalisation and organisational commitment: Evidence from Malaysia. International Business \& Economics Research Journal, 9(2), 49-57.

O'Reilly, C., \& Chatman, J. (1986). Organizational commitment and psychological attachment: the effects of compliance, Identification and Internalization on prosocial behaviour. Journal of Applied Psychology, 71(3), 492-499.

Özel, T. (2009). Örgütsel bağlılık ve tükenmişlik düzeyi: İstanbul ili vakıf üniversitelerinde görev yapan akademisyenlere yönelik bir alan araştırması (Yayımlanmamış Yüksek Lisans Tezi), Gazi Üniversitesi, Eğitim Bilimleri Enstitüsü, Ankara.

Pines, A.M. \& Aronson, E. (1988). Career burnout: Causes and cures. New York: Free Press.

Ransford, C. R., Greenberg, M. T., Domitrovich, C. E., Small, M., \& Jacobson, L. (2009). The role of teachers' psychological experiences and perceptions of curriculum supports on the implementation of a social and emotional learning curriculum. School Psychology Review, 38, 510-532.

Sajid, H. (2014). A Comparison of Organizational Commitment and Job Burnout among Teachers in Private and Public Institution with moderating effect of Job Satisfaction. Journal of Business and Management, 16(6), 29-33.

Salehi, M., \& Gholtash, A. (2011). The relationship between job satisfaction, job burn out and organizational commitment with the organizational citizenship behavior among members of faculty in the Islamic Azad University-first district branches, in order to provide the appropriate model. Procedia-Social and Behavioral Sciences, $15,306-310$.

Sarıkaya, E. (2011). İlköğretim ögrretmenlerinin örgütsel bağlllıkları ve performansları arasındaki ilişki (Yayımlanmamış Yüksek Lisans Tezi), Maltepe Üniversitesi, Sosyal Bilimler Enstitüsü, İstanbul.

Sezer, F. (2005). Illköğretim okulu müdürlerinin sergiledikleri liderlik stillerinin ögretmenlerin örgütsel bağlllı̆̆ına etkisi (Yayımlanmamış Yüksek Lisans Tezi), Gazi Üniversitesi, Eğitim Bilimleri Enstitüsü, Ankara.

Steers, R. M. (1977). Antecedents and outcomes of organizational commitment. Administrative Science Quarterly, 22(1), 46-56.

Swider, B. W., \& Zimmerman, R. D. (2010). Born to burnout: A meta-analyticpath model of personality, job burnout, and work out comes. Journal of Vocational Behavior, 76, 487-506. 
Tsui, K. T., \& Cheng, Y. C. (1999). School organizational health and teacher commitment: A contingency study with multi-level analysis. Educational Research and Evaluation, 5(3), 249-268.

Tümkaya, S. (1997). Çukurova Üniversitesi öğretim elemanlarının akademik tükenmişlik düzeyleri. 4. Ulusal Eğitim Bilimleri Kongresi. 10-12 Eylül, Eskişehir: Anadolu Üniversitesi Eğitim Fakültesi.

Uğurlu, C. T. (2009). Illköğretim okulu ögretmenlerinin örgütsel bağlllık düzeylerine yöneticilerinin etik liderlik ve örgütsel adalet davranışlarının etkisi (Hatay ili örneği) (Yayımlanmamış Doktora Tezi), İnönü Üniversitesi, Sosyal Bilimler Enstitüsü, Malatya.

Werang, B. R., Asmaningrum, H. P., \& Irianto, O. (2015). Relationship between teachers' job burnout, teachers' organizational commitment, and teachers' job performance at state elementary schools in Boven Digoel Regency, Papua, Indonesia. International Journal of Science and Research (IJSR), 4(2), 826-830.

Yılmaz Koca, S. (2009). Ortaöğretim okullarında görev yapan öğretmenlerin kişilik özellikleri ile örgütsel bağlllıkları arasındaki ilişkinin incelenmesi (Yayımlanmamış Yüksek Lisans Tezi), Yeditepe Üniversitesi, Sosyal Bilimler Enstitüsü, İstanbul.

Yılmaz, K., Altınkurt, Y., Güner, M., \& Şen, B. (2015). The relationship between teachers' emotional labor and burnout level. Eurasian Journal of Educational Research, 59, 75-90. 